\title{
Combustibility of lightweight foam concrete based on natural protein foaming agent
}

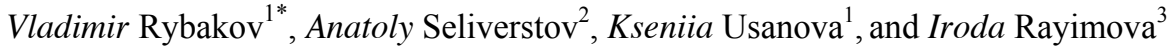 \\ ${ }^{1}$ Peter the Great St. Petersburg Polytechnic University, Politekhnicheskaya, 29, 195251, Saint- \\ Petersburg, Russia \\ ${ }^{2}$ Sovbi, Ltd, Ispolkomskaya st., 4-6, letter A, room 4H, office 1, 191024, Saint-Petersburg, Russia \\ ${ }^{3}$ Tashkent Institute of Irrigation and Agricultural Mechanization Engineers, Tashkent, Uzbekistan
}

\begin{abstract}
There is an experimental study of samples of monolithic foam concrete "SOVBI" with a density of $205 \mathrm{~kg} / \mathrm{m}^{3}$ (grade D200) for combustibility. The evaluation criteria are the following values of combustion characteristics: temperature increment in the furnace, duration of the stable flame burning, sample mass loss. The experimental results show the following values for foam concrete: temperature increment in the furnace of $2{ }^{\circ} \mathrm{C}$, duration of the stable flame burning of $0 \mathrm{~s}$, and sample mass of $24.4 \%$. Thus, monolithic foam concrete with a density of 205 $\mathrm{kg} / \mathrm{m}^{3}$ is noncombustible material. It is proposed to use monolithic foam concrete and other lightweight monolithic cellular foam concrete, as a structural fire protection for lightweight steel concrete structures. It, in turn, can increase the fire resistance of external walls and floor structure with the steel frame of cold-formed zinc-coated profiles.
\end{abstract}

\section{Introduction}

Monolithic foam concrete is used for enclosure structures in the form of lightweight steel concrete structures [1,2], retaining walls, and backfill materials for highways [3], railways, plazas [4]. This material is characterized by a low density, good sound insulating properties, and high thermal insulation capacity, while it exhibits sufficient compressive strength for the load-bearing function [5-8].

The use of monolithic foam concrete makes it possible to simplify and reduce the cost of construction and increase the volume of work more than ten times, compared with the laying of aerated concrete and foam concrete blocks, with a significant reduction in the number of workers. It also minimizes the use of crane and lifting and reduces transport expenses and the area of the zones of materials storage [9].

Monolithic foam concrete quality greatly depends on the type and quality of the foaming agent [10]. There are two types of foaming agents for monolithic foam concrete: protein foaming agent $[11,12]$ and synthetic foaming agent [13].

A synthetic foaming agent is cheaper than a protein foaming agent. Concrete based on synthetic foaming agent has shorter durability [14] and lower strength [15] compared to

*Corresponding author: fishermanoff@mail.ru 
concrete based on protein foaming agent. The protein foaming agent (vegetable based and animal based) has more suitable characteristics to produce foam concrete [14].

The researches [16-18] are devoted to the study of the pore structure of foam concrete. The use of fly ash as filler helps in achieving a more uniform distribution of air voids, which leads to an increase in the material strength [16]. Finer filler material helps in the uniform distribution of air voids [17]. A larger porosity results in a more significant effect of the moisture content on the effective thermal conductivity. When the volumetric moisture content reaches $10 \%$, the thermal conductivities of foam concrete and aerated concrete increases by approximately $200 \%$ and $100 \%$, respectively [18].

There are additives, such as fly ash [19-21] metakaolin [19, 22], shredded rubber [23, $24]$, silica fume $[25,26]$, granulated blast furnace slag $[27,28]$, which can improve the concrete properties.

The use of mineral additives regulates the porous structure of foam concrete; simultaneously, the coefficient of thermal conductivity is reduced, density is reduced, and frost resistance is improved [29].

Incorporation of various types of fibres can significantly improve the flexural strength (up to 4 times), tensile strength (up to 3 times), and impact strength (up to 6 times) [30].

Adding the calcium chloride and calcium oxalate in the amount of 2 and $0.5 \%$ of the cement mass, respectively, reduces the plastic shrinkage of the foam concrete mix by 47 $65 \%$ strength rises compressive strength from 0.31 to $0.47 \mathrm{MPa}$ (D400) and from 0.96 to $1.44 \mathrm{MPa}$ (D600) [31].

The research [32] is devoted to the combination of foam concrete and lightweight aggregates (pumice, expanded clay, and expanded perlite). The work shows an improvement in the compressive strength of such concrete by almost $40 \%$ compared to conventional foam concrete. The same applied to the drying shrinkage; the change in length is reduced by almost $80 \%$ [32].

Strength properties of foam concrete are shown in [10, 31, 33, 34]. The compressive strength of the foam concrete varies from $0.1 \mathrm{MPa}-12 \mathrm{MPa}$.

Thermotechnical characteristics of foam concrete are investigated in [1, 29, 35]. Coefficients of thermal conductivity of foam concrete depends on its density and it varies from $0.07 \mathrm{~W} /\left(\mathrm{m} \cdot{ }^{\circ} \mathrm{C}\right)-0.24 \mathrm{~W} /\left(\mathrm{m} \cdot{ }^{\circ} \mathrm{C}\right)$ [29]. Adding microspheres of perlite to foam concrete reduces its thermal conductivity coefficient to $0.062 \mathrm{~W} /\left(\mathrm{m} \cdot{ }^{\circ} \mathrm{C}\right)[35]$. The use of basalt and glass fiber, fine additives of wollastonite and diopside reduces the thermal conductivity coefficient to $0.069-0.097 \mathrm{~W} /\left(\mathrm{m}^{\circ} \mathrm{C}\right)$ [36]. The work [1] shows the experimentally obtained thermal conductivity resistance of the enclosure structure from thin-wall profiles with foam concrete. It is $1.367\left(\mathrm{~m}^{2} \cdot \mathrm{K}\right) / \mathrm{W}$, taking into account thermal resistance $0.783\left(\mathrm{~m}^{2} \cdot \mathrm{K}\right) / \mathrm{W}$ for reinforced sections.

However, there is little research on foam concrete as part of lightweight steel concrete structures (LSCS). The works [37], [38] show fire resistance of lightweight steel concrete structures consisting of profiled steel filled with a monolithic foam concrete with a 200 $\mathrm{kg} / \mathrm{m}^{3}-400 \mathrm{~kg} / \mathrm{m}^{3}$ density and with fiber cement sheets sheathing. The actual fire resistance limit of samples of the wall panel fragment is REI 60 with a uniformly distributed load of $20 \mathrm{kN} / \mathrm{m}$ [37]. The actual fire resistance limit of samples of the slab panel fragment is at least REI 60 with a uniformly distributed load of $4 \mathrm{kN} / \mathrm{m}^{2}$ [38].

Evaluating the effects of high temperatures on foam concrete used in lightweight steel concrete structures is of interest to understand the contribution to the overall fire resistance of these structures. This makes further research necessary.

This work aims to experimentally study the combustibility of monolithic foam concrete based on a protein foaming agent with a density of $200 \mathrm{~kg} / \mathrm{m}^{3}$ used for enclosure structures in the form of lightweight steel concrete structures. 


\section{Materials and Methods}

\section{a. Testing laboratory}

Monolithic foam concrete was tested in the testing centre «SZRC TEST» SZRC PB ltd (Leningrad Region, Russia).

\section{b. Concrete materials}

For the production of monolithic foam concrete, the following materials were used:

1. Portland cement CEM I $42.5 \mathrm{~N}$ manufactured by Oskolcement JSC (Belgorod region, Russia).

2. Protein hydrolysate foaming agent FOAMCEM manufactured by LastonSPA (Italy). The temperature range of the foam formation is from $-15 \mathrm{C}^{0}$ to $35 \mathrm{C}^{0}$. The foaming range is from $40 \mathrm{~g} / 1$ to $70 \mathrm{~g} / \mathrm{l}$.

3. Water of mixing. It meets the requirements of EN 1008:2002 ${ }^{*}$ "Mixing water for concrete. Specification for sampling, testing, and assessing the suitability of water, including water recovered from processes in the concrete industry, as mixing water for concrete".

The consumption of the concrete mixture components was selected for the preparation of lightweight foamed concrete with a density of $200 \mathrm{~kg} / \mathrm{m}^{3}$. Sand was not used as fine aggregate to achieve this density.

c. Concrete Mix Proportion

The concrete mixture was prepared using the SOVBI technology using a foam generator. Cement paste was prepared in a mortar mixer under normal pressure. After that, the finished foam was added to the cement paste from a separate foam generator until the mixture reached a predetermined volume. The unloading of the obtained foam concrete was carried out using a gerotor pump directly into the test mold.

Concrete mixing design to obtain samples of monolithic foam concrete "SOVBI" was carried out following the standard STO 06041112.002-2018 "Panels from steel concrete structures based on heat-insulating non-autoclave monolithic foam concrete, profile steel faced with fibrocement sheets".

Foam concrete of this composition refers to especially light in average density and the cellular structure.

Concrete mixtures are presented in table 1.

Table 1. Concrete mixtures.

\begin{tabular}{|c|c|c|c|}
\hline Cement $\left[\mathrm{kg} / \mathrm{m}^{3}\right]$ & Sand $\left[\mathrm{kg} / \mathrm{m}^{3}\right]$ & Water $\left[\mathrm{kg} / \mathrm{m}^{3}\right]$ & Foam $\left[1 / \mathrm{m}^{3}\right]$ \\
\hline 170 & - & 77 & 890 \\
\hline
\end{tabular}

The main characteristics of the obtained monolithic foam concrete are presented in table 2.

Table 2. Main characteristics of monolithic foam concrete.

\begin{tabular}{|c|c|c|}
\hline \multicolumn{2}{|c|}{ Monolithic foam concrete characteristic } & Value \\
\hline \multirow{4}{*}{$\begin{array}{c}\text { Thermal conductivity } \\
\text { coefficients, } \lambda \\
{\left[\mathrm{W} /\left(\mathrm{m} \cdot{ }^{\circ} \mathrm{C}\right)\right]}\end{array}$} & in dry state & 0.05 \\
\hline & at an equilibrium moisture content of $4 \%$ & 0.065 \\
\hline & at an equilibrium moisture content of $6 \%$ & 0.072 \\
\hline & at an equilibrium moisture content of $8 \%$ & 0.078 \\
\hline \multicolumn{2}{|c|}{ Vapor permeability coefficient, $\mu[\mathrm{mg} /(\mathrm{m} * \mathrm{~h} * \mathrm{~Pa})]$} & 0.28 \\
\hline \multicolumn{2}{|c|}{ Linear expansion coefficient, $\alpha_{\mathrm{bt}}$} & $0.8 * 10^{-5}$ \\
\hline \multicolumn{2}{|c|}{ Thermal diffusivity, $\chi\left[\mathrm{m}^{2} / \mathrm{h}\right]$} & $1.47 * 10^{3}$ \\
\hline \multicolumn{2}{|c|}{ Water absorption by volume [\%] } & 26 \\
\hline \multicolumn{2}{|c|}{ Density $\left[\mathrm{kg} / \mathrm{m}^{3}\right]$} & 205 \\
\hline
\end{tabular}




\section{d. Combustibility test}

For the combustibility test, 5 samples with a diameter of $43 \mathrm{~mm}$ and a height of $50 \mathrm{~mm}$ were prepared from a concrete mix (see table 1). The samples were conditioned in a ventilated heat chamber at the temperature of $(60 \pm 5){ }^{\circ} \mathrm{C}$ for $24 \mathrm{hrs}$. A hole with a diameter of $2 \mathrm{~mm}$ for installing a thermocouple in the geometric centre of the sample was provided in the upper part of the samples. During the test, the samples were placed in turn in the oven. Then, the readings of thermocouples were recorded in the furnace, at the centre, and on the surface of the sample. The test was terminated when the three thermocouples' readings changed by no more than $2{ }^{\circ} \mathrm{C}$ in 10 minutes.

After the test, the temperature rise in the furnace, on the surface of the sample, at the centre of the sample was calculated for each sample. Also, the mass loss for each sample was calculated.

The test was carried out at an air temperature of $18{ }^{\circ} \mathrm{C}$, atmospheric pressure of 102.5 $\mathrm{kPa}$, and relative humidity of $50 \%$.

The installation during testing is shown in figure 1 . The sample in the installation is shown in figure 2 .

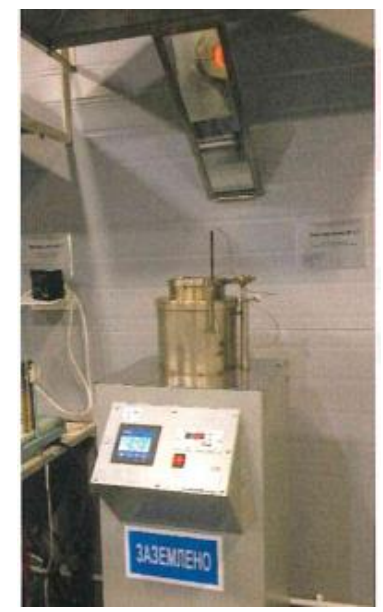

Fig. 1. Testing installation.

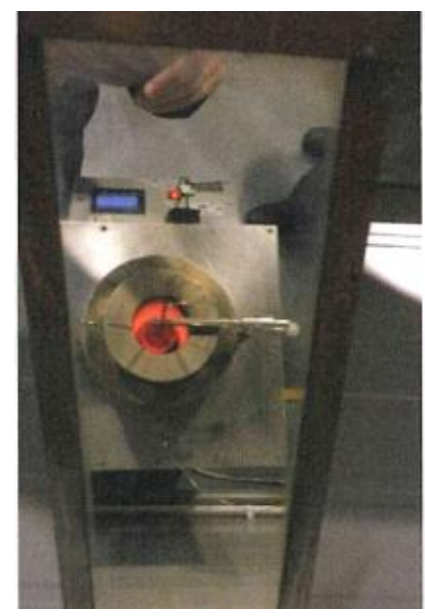

Fig. 2. The sample in the installation.

\section{Results and Discussion}

The experimental testing data are presented in table 3 and table 4 . The sample appearance after testing is presented in figure 3 .

Table 3. Mass loss of samples during testing

\begin{tabular}{|c|c|c|c|}
\hline \multirow{2}{*}{ № } & \multicolumn{2}{|c|}{ Sample mass [g] } & \multirow{2}{*}{ Mass loss [\%] } \\
\cline { 2 - 3 } & Before testing & After testing & \\
\hline 1 & 14.90 & 11.33 & 24.0 \\
\hline 2 & 16.34 & 11.73 & 28.2 \\
\hline 3 & 18.93 & 15.38 & 18.8 \\
\hline 4 & 17.32 & 13.47 & 22.2 \\
\hline 5 & 16.95 & 12.03 & 29.0 \\
\hline \multicolumn{3}{|c|}{ Average values } \\
\hline
\end{tabular}


Table 3 shows that the average mass loss of the samples is $24.4 \%$.

Table 4. Temperature values during testing

\begin{tabular}{|c|c|c|c|c|c|c|c|c|c|c|c|c|}
\hline \multicolumn{10}{|c|}{ Temperature $\left[{ }^{\circ} \mathrm{C}\right]$} & \multirow{2}{*}{\multicolumn{3}{|c|}{$\begin{array}{c}\text { Continuous } \\
\text { burning duration } \\
{[\mathrm{s}]}\end{array}$}} \\
\hline \multicolumn{4}{|c|}{ In the furnace } & \multicolumn{3}{|c|}{$\begin{array}{l}\text { On the surface of } \\
\text { the sample }\end{array}$} & \multicolumn{3}{|c|}{$\begin{array}{c}\text { At the centre of the } \\
\text { sample }\end{array}$} & & & \\
\hline : 襡 & 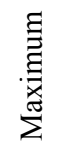 & 湆 & 节 & 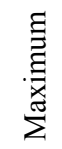 & 湆 & 莺 & 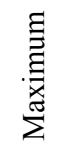 & 吾 & 莺 & . & 足 & .气 \\
\hline 745 & 804 & 802 & 2 & 784 & 782 & 2 & 768 & 767 & 1 & 0 & 0 & $\mathbf{0}$ \\
\hline 749 & 796 & 793 & 2 & 776 & 775 & 1 & 752 & 750 & 2 & 0 & 0 & $\mathbf{0}$ \\
\hline 748 & 804 & 802 & 2 & 786 & 784 & 2 & 770 & 769 & 1 & 0 & 0 & $\mathbf{0}$ \\
\hline 746 & 802 & 800 & 2 & 782 & 780 & 2 & 758 & 757 & 1 & 0 & 0 & $\mathbf{0}$ \\
\hline 748 & 802 & 799 & 3 & 778 & 776 & 2 & 754 & 754 & $\mathbf{0}$ & 0 & 0 & $\mathbf{0}$ \\
\hline \multicolumn{3}{|c|}{ Average values } & 2 & & & 2 & & & 1 & & & $\mathbf{0}$ \\
\hline
\end{tabular}

Table 4 shows that the temperature increments in the furnace and on the surface of the sample are $2^{\circ} \mathrm{C}$, at the centre of the sample is $1{ }^{\circ} \mathrm{C}$, and continuous burning duration is $0 \mathrm{~s}$.

Following Russian State Standard GOST 30244-94 "Building materials". Methods for combustibility test" the building materials are noncombustible under the following values of combustion characteristics: temperature increment in the furnace not more than $50^{\circ} \mathrm{C}$, duration of the stable flame burning not more than $10 \mathrm{~s}$, sample mass loss not more than $50 \%$. According to the results presented in Tables 2 and 3, foam concrete is a noncombustible material.

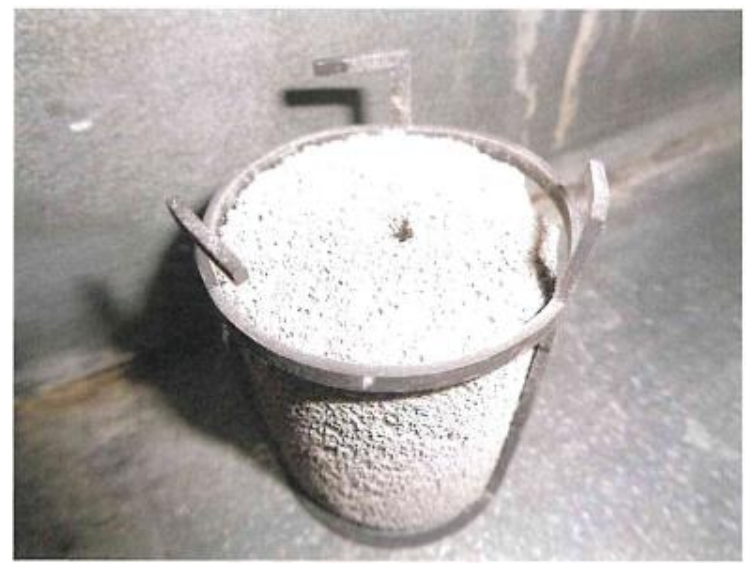

Fig. 3. The sample appearance after testing

By the results obtained, it is proposed to use monolithic foam concrete with a density of $200 \mathrm{~kg} / \mathrm{m}^{3}$ as a structural fire protection for lightweight steel concrete structures (LGSS), which in turn can increase the fire resistance of external walls and floor structure with the steel frame of cold-formed zinc-coated profiles.

It can also be concluded that lightweight steel concrete structures are noncombustible, which, in addition to foam concrete, is made of other noncombustible materials (profile steel and fiber cement sheets). 


\section{Conclusions}

Based on the results obtained, the following conclusions can be underlined:

1. Monolithic foam concrete with a density of $205 \mathrm{~kg} / \mathrm{m}^{3}$ (grade D200) is noncombustible material.

2. Lightweight steel concrete structures based on extra lightweight foam concrete are noncombustible.

3. It is proposed to use monolithic foam concrete with a density of $200 \mathrm{~kg} / \mathrm{m}^{3}$ and other especially lightweight monolithic cellular foam concrete, as a structural fire protection for lightweight steel concrete structures. It, in turn, can increase the fire resistance of external walls and floor structure with the steel frame of cold-formed zinc-coated profiles.

\section{Funding}

This work is supported by the Russian Science Foundation under grant 21-19-00324.

\section{References}

1. Rybakov, V.A., Ananeva, I.A., Pichugin, E.D., Garifullin, M.: Heat protective properties of enclosure structure from thin-wall profiles with foamed concrete. Mag. Civ. Eng. 94, 11-20 (2020). https://doi.org/10.18720/MCE.94.2.

2. Rybakov, V., Seliverstov, A., Petrov, D., Smirnov, A., Volkova, A.: Lightweight steel concrete structures slab panels load-bearing capacity. MATEC Web Conf. 245, (2018). https://doi.org/10.1051/matecconf/201824508008.

3. Cao, H.: Analysis of mechanical properties of transition segment of road and bridge based on high-strength foam concrete. Frat. ed Integrita Strutt. 13, 831-839 (2019). https://doi.org/10.3221/IGF-ESIS.49.73.

4. Song, Z., Lu, Z., Lai, Z.: The effect of lithium silicate impregnation on the compressive strength and pore structure of foam concrete. Constr. Build. Mater. 277, 122316 (2021). https://doi.org/10.1016/j.conbuildmat.2021.122316.

5. Fediuk, R., Amran, M., Vatin, N., Vasilev, Y., Lesovik, V., Ozbakkaloglu, T.: Acoustic Properties of Innovative Concretes: A Review. Materials (Basel). 14, 398 (2021). https://doi.org/10.3390/ma14020398.

6. Mechtcherine, V., Markin, V., Will, F., Näther, M., Otto, J., Krause, M., Nerella, V.N., Schröfl, C.: Production of monolithic, load-bearing, heat-insulating wall structures by additive manufacturing with foam concrete. Bauingenieur. 94, 405-415 (2019).

7. Sherbin, S.A., Gorbach, P.S.: Foam concrete production with addition of microsilica. IOP Conf. Ser. Mater. Sci. Eng. 880, (2020). https://doi.org/10.1088/1757899X/880/1/012021.

8. Lesovik, V., Voronov, V., Glagolev, E., Fediuk, R., Alaskhanov, A., Amran, Y.H.M., Murali, G., Baranov, A.: Improving the behaviors of foam concrete through the use of composite binder. J. Build. Eng. 31, $101414 \quad$ (2020). https://doi.org/10.1016/j.jobe.2020.101414.

9. Sychova, A., Solomahin, A., Kotovich, V., Svatovskaya, L., Kamenev, Y.: Improving of the monolithic foamconcrete quality for used in the high-rise constructions. E3S Web Conf. 33, (2018). https://doi.org/10.1051/e3sconf/20183302058.

10. Gailitis, R., Korniejenko, K., Sprince, A., Pakrastins, L.: Comparison of the long-term properties of foamed concrete and geopolymer concrete in compression. AIP Conf. Proc. 2239, 20003 (2020). https://doi.org/10.1063/5.0007787.

11. Kuzielová, E., Pach, L., Palou, M.: Effect of activated foaming agent on the foam 
concrete properties. Constr. Build. Mater. 125, 998-1004 (2016). https://doi.org/10.1016/j.conbuildmat.2016.08.122.

12. Montayev, S.A., Shakeshev, T., Muratbai, Z., Ryskaliyev, N., Bolatovna, A., Narikov, K.A., Khan, Z., Kazakhstan, W.: COLLAGEN AGENT TECHNOLOGY FOR FOAM CONCRETE PRODUCTION. 12, (2017).

13. Kadela, M., Kukiełka, A., Małek, M.: Characteristics of lightweight concrete based on a synthetic polymer foaming agent. Materials (Basel). 13, 1-15 (2020). https://doi.org/10.3390/ma13214979.

14. Falliano, D., Restuccia, L., Gugliandolo, E.: A simple optimized foam generator and a study on peculiar aspects concerning foams and foamed concrete. Constr. Build. Mater. 268, 121101 (2021). https://doi.org/10.1016/j.conbuildmat.2020.121101.

15. Falliano, D., De Domenico, D., Ricciardi, G., Gugliandolo, E.: Key factors affecting the compressive strength of foamed concrete. IOP Conf. Ser. Mater. Sci. Eng. 431, 062009 (2018). https://doi.org/10.1088/1757-899X/431/6/062009.

16. Nambiar, E.K.K., Ramamurthy, K.: Air-void characterization of foam concrete. Cem. Concr. Res. 37, 221-230 (2007). https://doi.org/10.1016/j.cemconres.2006.10.009.

17. Ramamurthy, K., Kunhanandan Nambiar, E.K., Indu Siva Ranjani, G.: A classification of studies on properties of foam concrete. Cem. Concr. Compos. 31, 388-396 (2009). https://doi.org/10.1016/j.cemconcomp.2009.04.006.

18. Liu, Y., Ma, C., Wang, D., Wang, Y., Liu, J.: Nonlinear Effect of Moisture Content on Effective Thermal Conductivity of Building Materials with Different Pore Size Distributions. Int. J. Thermophys. 37, 1-27 (2016). https://doi.org/10.1007/s10765016-2062-0.

19. Deepak, N., Thiagu, H., Manivel, S.: STUDY ON STRENGTH OF METAKAOLIN BASED FOAMED CONCRETE UNDER DIFFERENT ELEVATED TEMPERATURE. ARPN J. Eng. Appl. Sci. 14, 2980-2986 (2019).

20. Vatin, N., Barabanshchikov, Y., Usanova, K., Akimov, S., Kalachev, A., Uhanov, A.: Cement-based materials with oil shale fly ash additives. IOP Conf. Ser. Earth Environ. Sci. 578, 012043 (2020). https://doi.org/10.1088/1755-1315/578/1/012043.

21. Lesovik, V., Glagolev, E., Voronov, V., Zagorodnyuk, L., Fediuk, R., Baranov, A., Alaskhanov, A., Svintsov, A.: Durability behaviors of foam concrete made of binder composites. Mag. Civ. Eng. 100, 10003-10003 (2021).

22. Deepak, N., Thiagu, H., Manivel, S.: STUDY ON STRENGTH OF METAKAOLIN BASED FOAMED CONCRETE UNDER DIFFERENT ELEVATED TEMPERATURE. 14, (2019).

23. Benazzouk, A., Douzane, O., Mezreb, K., Quéneudec, M.: Physico-mechanical properties of aerated cement composites containing shredded rubber waste. Cem. Concr. Compos. 28, 650-657 (2006).

24. Eltayeb, E., Ma, X., Zhuge, Y., Youssf, O., Mills, J.E.: Influence of rubber particles on the properties of foam concrete. J. Build. Eng. 30, 101217 (2020). https://doi.org/10.1016/j.jobe.2020.101217.

25. Koksal, F., Sahin, Y., Gencel, O.: Influence of expanded vermiculite powder and silica fume on properties of foam concretes. Constr. Build. Mater. 257, 119547 (2020). https://doi.org/10.1016/j.conbuildmat.2020.119547.

26. Barabanshchikov, Y., Usanova, K., Akimov, S., Uhanov, A., Kalachev, A.: Influence of electrostatic precipitator ash "zolest-bet" and silica fume on sulfate resistance of Portland cement. Materials (Basel). 13, 1-13 (2020).

27. Oren, O.H., Gholampour, A., Gencel, O., Ozbakkaloglu, T.: Physical and mechanical properties of foam concretes containing granulated blast furnace slag as fine aggregate. Constr. Build. Mater. 238, 117774 (2020).

28. Barabanshchikov, Y., Usanova, K., Akimov, S., Bílý, P.: Low heat concrete with 
ground granulated blast furnace slag. In: IOP Conference Series: Materials Science and Engineering. IOP Publishing Ltd (2020). https://doi.org/10.1088/1757899X/896/1/012098.

29. Bartenjeva, E.: The effect of mineral additives on foam concrete porosity. IOP Conf. Ser. Mater. Sci. Eng. 962, 022023 (2020). https://doi.org/10.1088/1757899X/962/2/022023.

30. Amran, M., Fediuk, R., Vatin, N., Lee, Y.H., Murali, G., Ozbakkaloglu, T., Klyuev, S., Alabduljabber, H.: Fibre-reinforced foamed concretes: A review. Materials (Basel). 13, 1-36 (2020). https://doi.org/10.3390/ma13194323.

31. Steshenko, A.B., Kudyakov, A.I., Ryabtseva, N.E.: Cement based foam concrete with hardening accelerators. IOP Conf. Ser. Mater. Sci. Eng. 911, (2020). https://doi.org/10.1088/1757-899X/911/1/012003.

32. Schumacher, K., Saßmannshausen, N., Pritzel, C., Trettin, R.: Lightweight aggregate concrete with an open structure and a porous matrix with an improved ratio of compressive strength to dry density. Constr. Build. Mater. 264, 120167 (2020). https://doi.org/10.1016/j.conbuildmat.2020.120167.

33. Rybakov, V., Seliverstov, A., Petrov, D., Smirnov, A., Volkova, A.: Strength characteristics of foam concrete samples with various additives. MATEC Web Conf. 245, (2018). https://doi.org/10.1051/matecconf/201824503015.

34. Johnpaul, V., Abiraami, R., Sindhu, R., Balasundaram, N., Solai Mathi, S.: High Strength Lightweight Foam Concrete. IOP Conf. Ser. Mater. Sci. Eng. 1006, (2020). https://doi.org/10.1088/1757-899X/1006/1/012013.

35. Bartenjeva, E.: The increase of heat-insulating properties of foam concrete by introducing mineral additives. IOP Conf. Ser. Mater. Sci. Eng. 456, (2018). https://doi.org/10.1088/1757-899X/456/1/012036.

36. Mashkin, N., Bartenjeva, E.: Research of structuring processes of non-autoclave foam concrete with introduction of mineral additives. IOP Conf. Ser. Mater. Sci. Eng. 451, (2018). https://doi.org/10.1088/1757-899X/451/1/012018.

37. Rybakov, V., Seliverstov, A., Urmanceva, K.: Lightweight steel-concrete wall bearing structures under high-temperature exposure. Lect. Notes Civ. Eng. (2021).

38. Rybakov, V., Seliverstov, A., Urmanceva, K.: Fire resistance of lightweight steelconcrete slab panels under high-temperature exposure. (2021). 